\title{
From Binary to Intersectional to Imbricated Approaches: Gender in a Decolonial and Diasporic Perspective
}

\section{Andréa Gill ${ }^{*}$ \\ Thula Pires*}

\begin{abstract}
This article proposes a re-reading of the problem of gender, or as it has been put, more often than not, 'the woman problem,' that resists the reproduction of modern/colonial systems of governance and their political norms, standards, ideals and pacts. In turn, it seeks to open pathways to dialogue with, rather than import, conceptions of gender that respond to the terms through which modern/colonial societies have been forged on the continent of Abya Yala, drawing inspiration from decolonial and diasporic perspectives. To this end, the article maps some of the available channels of the gender debate in what has come to be known as the global South from an array of perspectives that highlight the ways in which the relations between categories of oppression and privilege (such as race, class, sexuality and gender) are reflected and positioned so as to grapple with the coloniality of knowledge, power and being. More specifically, it focuses on three ways of dealing with power dynamics in the context of Abya Yala that have influenced how we conceive and respond to questions of gender. Its primary objective is to investigate the politico-epistemic conditions that structure gender thinking in binary and intersectional ways, and, in turn, open space for imbricated approaches forged from within (post-)colonial histories that do not take as their starting point the importation of theoretical references from places otherwise situated within a global political economy of knowledge/power/being. More than a critique of theoretical standpoints from the global North, in and of themselves, which regardless were not thought to respond to our realities, here we analyse the terms through which gender and feminisms have been put up for debate. Without effectively decentring the Eurocentred references that preoccupy gender thinking in our respective disputes, we risk continued distraction from what is at stake when gender is put on the table: the (im)possibilities of living one's full humanity on one's own terms.
\end{abstract}

Keywords: intersectionality; imbrication; decoloniality; gender; race; amefricanity; Abya Yala.

\footnotetext{
* Pontifical Catholic University of Rio de Janeiro (PUC-Rio), Rio de Janeiro-RJ, Brazil; andrea.b.gill@gmail. com. ORCID iD 0000-0003-0038-2582.

** Pontifical Catholic University of Rio de Janeiro (PUC-Rio), Rio de Janeiro-RJ, Brazil; thula@puc-rio.br. ORCID iD 0000-0003-2138-5483.
} 


\section{Introduction}

To speak of gender is to speak of the categorisations of humanity. Any shortcut mapped through other means will remain lost in distracted debates about decontextualised individuals or collectives, their special issues and so-called differences, measured in relation to unnamed hegemonic standards, identitarian norms and ruling pacts. Hence it becomes vital, as a first step towards such difficult global dialogues, to recognise how practices of (de)humanisation structure the conceptual and political field of (im)possibilities when discussions of gender are put on the table. And here, voices from the post-colonies have ceaselessly brought to the fore what gets lost in translation when the measure of intelligibility is set by the (self)authorising languages of our once colonisers (Anzaldúa 2000; Bairros 1995; Oyèwùmí 2004; Spivak 1997; Vigoya 2018) in ways that effectively deny forms of perceiving our historic constitutions proper to the geopolitical conditions through which diverse bodies and experiences are socially and politically produced.

It is not of a recent turn to demand that we grapple with how our Eurocentred histories, concepts and methods capture any attempt at thinking through the (im)possibilities of our inherited present. Many critical voices, from margins and centres variously located, have made this call to deal with the coloniality of knowledge, power and being that reflects and reproduces a global racist-sexist-capitalist system (Bernardino-Costa and Grosfoguel 2016). Yet the struggle to find a voice, intelligible within and beyond the hegemonic terms of our political and conceptual imaginary, has generated backlash and debate overwhelmingly constrained by the prevailing modern scientific logic that pits universal against relative or particular ways of thinking.

If we are to take seriously the proposals for epistemologies of the South (Meneses and Santos 2010), it is imperative to break free from such rigid terms and conditions, framed as neutral, which impede the advancement of the production of a system of knowledge that does not merely guarantee itself through self-containment by way of monological qualifications of internal consistency and self-referentiality. When we are able to give up on this solipsistic attachment disguised as scientific rigour, we may begin to feel out what resonates, where, when, and to what effects, and accordingly rework our criteria for evaluating critical thinking and praxis. To ask, 'What serves us?' is not a corruption of the prized neutrality of academic thought, but precisely the kind of political thinking necessary to take on such difficult dialogues into the gendering, racialising and classed practices that, together with innumerous hierarchised categorisations of our humanity, sustain the inequalities and violences that mark the contemporary world.

How, then, are we to embark on a re-reading of the problem of gender, or as it has been put more often than not 'the woman problem,' that does not reproduce the ethos of our modern/colonial world? With its universal histories and subjects predicated upon a totalising distinction between man and woman, and the consequent attribution of the source of gender oppression to a sort of all-subsuming patriarchal structure, feminist debates can sometimes hinder as much as they help guide such difficult dialogues.

For too long the terms through which gender is conceived have been haunted by the political and epistemic standards authored by the logic of a white capitalist cisheteronor- 
mative masculinity. In the shadow of the white man, feminists have declared themselves oppressed, have sought equality with and validation in the eyes of those deemed responsible for the violences and inequalities of this world, or at the very least, for their own lived oppressions.

The reorientations brought by black feminism, womanism, queer studies, masculinity studies, disability studies, among other critical currents of thought that provincialise these mythical hegemonic standards have gone a long way in reworking the possible space for political reflection and action. Yet until the terms of departure and reference are effectively re-centred, the (im)possibilities of political dispute remain captured in the image of whomever we seek to respond to. And everyone else remains fated to alterity, particularity, or relativism, obstructed from defining identity and difference, norm and exception, among other collective markers of political community on their own terms.

Recognising the unequal terms and local specificities through which we enter into such interepistemic and intercultural exchanges, we here propose pathways to dialogue with, rather than import, conceptions of gender that respond to the terms through which modern/colonial societies have been forged on the continent of Abya Yala, drawing inspiration from decolonial and diasporic perspectives. To this end, this article aims to map some of the available channels of the gender debate in what has come to be known as the global South from an array of perspectives that highlight the ways in which the relations between categories of oppression and privilege (such as race, class, sexuality and gender) are reflected and positioned so as to grapple with the coloniality of knowledge, power and being. We begin with Abya Yala in its indigenous naming, resisting the interpretive grid of the territory's later designation as 'Latin America' in a Eurocentred retelling of its origin story and eventual subjugation to an imperial America to the north that dispenses qualifications of the likes of Latinity to guarantee its tie to Europe.

More specifically, this collaborative work in progress focuses on three ways of dealing with power dynamics in the context of Abya Yala that have influenced how we conceive and respond to questions of gender. Our objective is to investigate the politico-epistemic conditions that structure gender thinking in binary and intersectional ways, and, in turn, open space for imbricated approaches forged from within (post-)colonial histories that do not take as their starting point the importation of theoretical references from places otherwise situated within a global political economy of knowledge/power/being. More than a critique of theoretical standpoints from the global North in and of themselves, which regardless were not thought to respond to our realities, we here analyse the terms through which gender and feminisms have been put up for debate. Without decentring the Eurocentred references that preoccupy gender thinking in our respective disputes, we risk continued distraction from what is at stake when gender is put on the table: the (im) possibilities of living one's full humanity on one's own terms.

The first politico-epistemic proposition that we pose for investigation, foundational to Eurocentred gender thinking, takes a binary approach to oppressor/oppressed relations so as to identify the kind of dynamics of oppression (e.g. masculine/feminine, white/nonwhite, heterosexual/homosexual) operating in modern intersubjective and institutional relations, while securing the centrality of the concept of patriarchy to gender thinking. 
The second politico-epistemic proposition that we reflect upon here mobilises the notion of intersectionality, as proposed by black feminists in the USA, to incorporate conjunctures between pre-established categories such as gender, race, class and sexuality, in order to complexify and situate local axes of oppression. Finally, the politico-epistemic proposition derived from a method of imbrication, presented in the third section of this article under the rubric of decolonial studies in the context of Abya Yala, offers the possibility of dealing in structural and structuring terms how our humanities have been racially hierarchised - in their respective positions within what Frantz Fanon (2008) denominated as the

zone of being and zone of non-being set up by coloniser/colonised relations - and informed by gender, sexuality, class, territory, age, ability, religion, nationality, among other systems of classifications forged from within the European modern/colonial project later potentialised by the politics of US imperialist practices and local post-colonial elites.

Each of these analytical modes opens up distinct ways to configure the gender debate, in which varied theoretical standpoints and -isms are cultivated. It thus follows that the central purpose of the article is to articulate the politico-epistemic conditions necessary to deal with what has been categorised as the problems of gender in context, notably of the global South in dispute, in ways that go beyond the binary and intersectional categories inherited by the modern/colonial project, while remaining attentive to their many imbued lessons and manoeuvres. Given that within the zone of non-being the category of sex has been employed to classify animalised subjects whose humanity has been negated as a result of centuries of colonial slavocratic exploitation, the category of gender, designed to give an account of the zone of being, is inherently limited in its analytical potential if not taken in ways imbricated with multiple systems of domination. More than an intersecting of given categories on a level playing field, we argue here that any mobilisation of the gender category that seeks to decolonise the structures in which it is inserted must be understood transversally across a hierarchised domain. Feminist theories that work with isolated variables, additive approaches or mutually exclusive oppositions, in effect, limit our political imaginaries in ways that are unable to give an account for the kinds of violences and inequalities that structure (post-)colonial societies. In the context of the colonial slavocratic history that founded modern societies in Abya Yala, contemporary challenges require that gender, more than a question of individual or collective identities, be taken as a force that positions us in society and that allows us to respond to the demands of the world that we have inherited, each and every one of us in and from our own place.

\section{Binary optics: the master/slave dialectic within the conceptual genealogies of Eurocentred gender thinking}

There is a long tradition within the modern westernised canon that sets out to interpret relations of domination through some variation of the master/slave dialectic. Practices of critique so informed focus in on a binary, or more precisely put, dialectic encounter between opposing and mutually exclusive forces that mediates their (self-)recognition and relative positioning in ostensibly interdependent ways. 
From the Hegelian-cum-Marxian inspired debates about dialectic modalities of power and resistance, we have inherited a tradition of critique that has worked and reworked the possibilities of political struggle, even if within teleological and totalising structures, centring the problem of (dis)alienation as the key to unlocking the processes of oppression towards the prospect of emancipation from objecthood. Staying off the limits of individuality and hybridity as interpretative frames of power, the field of dynamic opposition brought into play through a dialectic method permanently revitalises itself by zeroing in on antagonistic dynamics that cut across borders of varied sorts, and, in effect, mobilise possibilities of systemic critique by identifying the internal nature of opposition (contradiction) deemed capable of imploding or uniting the structure of the antagonistic relationship at hand.

Whether rendered phenomenologically, ontologically, or existentially, this kind of method of analysis, which abstracts the movements and dynamics of history, puts forward a conception of freedom, autonomy and subjectivity that reflects and reproduces the terms and conditions necessary to enter into the political pacts that sustain modern systems of governance. Binary approaches to relations of power have a long history in the modern social sciences and humanities, where they have been taken up as an interpretive framework, for instance, for Marxian conceptions of class struggle as the motive force of social development (perhaps most notably in the 1844 Manuscripts, Grundrisse and German Ideology); for post-colonialist conceptions of coloniser/colonised relations grounded in the encounter of self and other (in contemporary re-articulations of Edward Said's Orientalism and of varied scholars of subalternity); and for feminist conceptions of patriarchal oppression (of the likes of Simone de Beauvoir's foundational account of the dynamics of gender relations in The Second Sex, and Anglo-Saxon renditions of the social/ sexual contract). At their core are debates over the preconditions of subjectivity, established in and through an emancipation from objecthood. What these dialectic renderings enable us to see, at their best, perhaps, are the terms of such mediation and the supports of the internal logic of domination.

In this spirit, feminist re-articulations of a binary model of oppression took force with the French existentialist mantra now widespread in its many waves and currents that one is not born a woman (i.e. essence) but becomes one (i.e. existence) (Beauvoir 2011). Beauvoir's legacy imprinted the sex/gender distinction within feminist thought, that is, the centrality of the distinction between the biologically given and the socio-historically constructed, shifting the source of women's oppression to the latter dynamic as an intended emancipatory move. In turn, sexual difference became centred in prevailing conceptions of gender.

Beauvoir (2011: 26) defines woman as the 'second sex' because of the ways in which women are inscribed in relation to men, as the other that deviates or differs from the autonomous, self-explanatory, neutral conception of humanity, individuality and subjectivity. Although she gestures at other forms of oppression that are also thought to work through this othering dynamic, such as race and class, she (as with most Eurocentred feminists) centres patriarchy as the organising unit of society. And indeed, the concept of pa- 
triarchy has informed, to a large extent, how critical Eurocentred thought makes sense of gender, oftentimes in isolation from other gendered systems of oppression and privilege.

In Beauvoir's (2011: 26) words, the gendered dialectic can be understood in the following ways:

Thus humanity is male and man defines woman not in herself but as relative to him; she is not regarded as an autonomous being. [...] She is defined and differentiated with reference to man and not he with reference to her; she is the incidental, the inessential as opposed to the essential. He is the Subject, he is the Absolute - she is the Other.

The category of the Other is as primordial as consciousness itself. [...] Thus it is that no group ever sets itself up as the One without at once setting up the Other over against itself.

In the introduction of The Second Sex, Beauvoir (2011: 23) poses the question, 'What is a woman?' and as such, in demonstrating how the absolute human type is masculine, argues that woman is accordingly defined by lack, and so at stake is not a question of (as) symmetry, but rather the very structure that designates available subject positions. This feminist classic has become a key reference for how to think about this kind of relationality between the masculine and the feminine beyond its apparent asymmetry. Beauvoir (2011: 25) sums up:

The terms masculine and feminine are used symmetrically only as a matter of form, as on legal papers. In actuality the relation of the two sexes is not quite like that of two electrical poles, for man represents both the positive and the neutral, as is indicated by the common use of man to designate human beings in general; whereas woman represents only the negative, defined by limiting criteria, without reciprocity.

As follows, complementarity, inversion and lack are just some of the dominant isomorphic and dimorphic conceptions of gender (Bento 2006: 109) that continue to thrive within feminist debates that define the terms through which gender is conceived within a binary frame.

From this formative tradition of feminist thinking, which investigates how woman has been defined as the other within a system of what Beauvoir calls male supremacy, the conditions of dialectical difference and the ways through which antagonism is constructed reflect their centred point of reference, the man in charge. In Part II of The Second Sex, 'On Master-Slave Relations,' Beauvoir poses a question repeatedly reengaged in feminist theorising regarding how man effectively assumes mastery in and through confrontation with woman and all that is deemed feminine (nature, the body, the senses, etc.) that is poised to threaten the exercise of rational (self-)control: 
What place has humanity made for this portion of itself which, while included within it, is defined as the Other? What rights have been conceded to it? How have men defined it? (Beauvoir 2011: 112; italics ours).

Such reinterpretations of what constitutes humanity (and its internal struggles) are responding to a prevailing disposition within Eurocentred thought that has tended to approach domination in binary terms. Within these interventions, the internal nature of opposition and the force of contradictions move the binary dynamic and its (dis)identifications, negating the possibility of dealing with incommensurable processes, logics and structures through the totalising position of the subject and the object of political thought and action.

Within the social contract tradition, for instance, we have come to see the application of similarly self-contained and totalising visions of the world to the institutional ordering of society as one of the formative bases for the modern science of politics. That is, we are talking about a foundational myth whereby a conceptual repertoire is mobilised to explain how political subjects are thought to have given up their unrestrained power (read: freedom) in the 'state of nature' to constitute society under the guarantee of security and protection, in a kind of obedience/protection trade-off rendered in terms of political mastery and civil subordination. Feminist critiques of the idea of the social contract - of the likes of Carole Pateman (1988) and Susan Okin (1989) - draw attention to how the contract model, articulated through the language of neutrality, individuality and universality, veils and legitimates relations of mastery and subordination as a kind of free dispute of consenting equals within the structures of modern governing institutions, notably through the language of democracy and free markets. In short, through these feminist critiques of power, we begin to make out a patriarchal pact that subordinates the very subjects that service and enable its dominion. Otherwise put, an unnamed and invisiblised sexual contract (in its perhaps most manifest form: marriage) serves as the condition of possibility for the social contract as we have come to know it to articulate modern democracy in a westernised canon of social and political thinking. Although not all forms of civil subordination are identified within Pateman's (1988) influential critique of the social/sexual contract as assuming patriarchal forms (at times, even a fratriarchal dynamic is brought to bear), the subject and the object of the contract tend to be articulated in terms of the universal and fixed positions of man and woman, the latter subject to private rather than public rule under some variation of a patriarchal pact. Through these critical reinterpretations of the gendered structure of domination, we are led to make out who has power and who does not, the oppressor and the oppressed, the visible and the invisible and so on and so forth.

The binary lens allows us to make out two parts to a whole. As Beauvoir signals, its field of vision is not asymmetrical, however unequal. In and through the dialectic, it becomes possible to combat domination, even if on the oppressor's terms. Therein lies the access point, the mirror, whether broken or reflective of the standards, ideals and pacts of a recognised humanity. This becomes all the more evident when we face the practices of 
dehumanisation that disqualify the majority of people on the planet from the possibility of occupying the place of the opposing force in the dialectic. Here, the anticolonial political struggles that Fanon brings to bear on processes of collective liberation have much to teach us about this matter.

In brief, Fanon's response to a dialectic conception of relations of power opens way for an account of the logic and operation of coloniality, of multiple imbricated hierarchies set within a racialised (de)classification of humanity, as we will explore further in the third section presented here under the rubric of decoloniality. Whether we follow the theoretical camps that interpret Fanon's work as rejecting or reworking a Hegelian master/slave dialectic, it is important to keep in mind that dialectic conceptions of power were not thought to explain historical regimes of slavery, and, instead, propose pathways towards freeing oneself from and ultimately transcending the conditions to which one is subjected.

If we read Fanon's writings on the psychic life of power as offering a comprehensive critique of colonialism, attentive to the effects of colonial domination on all involved, then we see that his is a situated analysis in which instead of absolute or reciprocal recognition, the dynamic is marked by the constant dislocation of what he calls the 'unreflected position' (Fanon 2008: 103) of the colonised black subject, for whom the idea of subjectivity, ontology, epistemology and the whole apparatus of modern/colonial sciences and humanities, based on a white myth of individuality, is inapplicable. Once we understand how the structures of coloniality and its governing white supremacist logic establish the terms of possible (dis)qualification that position non-white subjects within a zone of non-being, the question of entering into the dialectic can be understood as a matter of political struggle, the aim of an anti-racist movement, in Fanon's terms, and not a description of actual positions occupied. More than the other side of an oppositional relation, the position of the black colonised subject is that which must be excluded in order for the self/other to exist. Prior to thinking categories and methods of analysis, it is imperative to grapple with how we are speaking to practices of (de)humanisation, and, as the original doctoral dissertation title of Black Skin, White Masks puts it, 'An essay on the disalienation of the black' as the radical movement capable of dislocating the field of dynamic oppositions. At stake is the dismantling of the solipsistic structure that hierarchises humanity through the unnamed standards, norms and pacts of whiteness, which in (post-)colonial societies is the ultimate mark, representative and gatekeeper of Europeneity (read: modern civilisation).

In sum, the dialectic only applies to those who are positioned in such a way as to be considered for qualification or disqualification on the terms set by colonial structures of knowledge, power and being. So it is important to remain attentive to how binary categories help and hinder an analysis at hand of what, when, where and with whom. As Fanon exemplifies in his study of (dis)alienation,

Ontology-once it is finally admitted as leaving existence by the wayside-does not permit us to understand the being of the black man. For not only must the black man be black; he must be black in relation to the white man. Some critics will take it on themselves to remind us that this proposition has a converse. I say that this is false. 
The black man has no ontological resistance in the eyes of the white man (2008: 82-83).

With the phrase, 'I was responsible at the same time for my body, for my race, for my ancestors', what Fanon termed a 'racial epidermal schema,' articulated through historical relations founded on the European colonial slavocratic project, made it that 'it was no longer a question of being aware of my body in the third person but in a triple person' (Fanon 2008: 84, italics ours).

There are many forms of objectification, oppression and dehumanisation which are not resumed by a dialectic dynamic. Within the zone of being, particular dynamics of oppression and privilege play out mediated by racial privilege, and within the zone of non-being the dynamics of oppression and privilege that have force are also specific to the given racialised structural positioning (Grosfoguel 2016: 7). These intra-/inter-dynamics together sustain a colonial structure of being, knowledge and power, although they operate and pass through different codes, standards and pacts. Whereas in the zone of being one is positioned as a potential subject of rights and knowledge, passable of dialectic dispute, in the zone of non-being the dominant mode of resolution is violence and expropriation (Grosfoguel 2016: 7). That is, the key distinction is that there is a certain dispensability or disposability to the condition of those situated within the zone of non-being, whose lives, deaths and deaths-in-life go systematically unregistered, positioned in such ways that are not capable of intervening in public debate and policy in compatible registers. As Fanon (2008: 172) puts it of (post-)colonial societies, in the concluding movements of Black Skin, White Masks,

I hope I have shown that here the master differs basically from the master described by Hegel. For Hegel there is reciprocity; here the master laughs at the consciousness of the slave. What he wants from the slave is not recognition but work.

It is imperative to situate our analytical tools, work against emptying out concepts in an aspired universal applicability (such as has been the fate of the concept of the other now oversaturated with conflated claims), and not confuse the diagnostic with the symptomatic in order to sharpen our capacity to discern how relations of power operate in all of their complexity and ambiguity. But for now, to complete the Sartrean thread in this modern/ colonial story of the dialectic of domination and servitude, the Frenchman who popularised the interpretive turn to the Hegelian master/slave dialectic as a lens through which to apprehend Marxian class struggle, and whose existentialist project oriented the works of the likes of both Beauvoir and Fanon, exemplifies for us what a binary approach to society implicates. In its categorisations of subjecthood and objecthood, self and other, identity and difference, any approach that essentialises through some kind of separation of nature from culture will end up reproducing the modern/colonial categorisations of our humanities, such as through the hegemonic categories of gender, race and sexuality. The problem with the essence/existence divide is its decontextualised and totalised articulations of what ultimately is co-constitutive. In a world marked by multiple authorities, resistances and 
violences, it is necessary to situate that which we seek to understand so as to access its

governing logics on its own terms. As such, it becomes vital to hone our capacity to deal with contradiction as functionally compatible, and grasp the incommensurabilities that separate more than what can be rendered visible within the dominant frame of analysis.

In the case of gender, the universal category of woman, rendered dialectically in relation to man, ends up being synonymous to the position of wife within the patriarchal structure idealised as the politico-epistemic basis of Eurocentred feminisms and conceptions of gender, as the works of Oyèrónké Oyèwùmí (2000) put forward in her Afrocentred critique of the field. In this way, it becomes impossible to conceptualise the gendering of racialised, classed and territorial relations of all sorts, presumed to be absent in the home and domestic sphere centred paradigmatically as a result.

To put it more concretely, to speak of gender in terms of man/woman, to speak of race in terms of white/black, to speak of class in terms of rich/poor, to speak of ability in terms of abled/disabled, to speak of sexuality in terms of heterosexual/homosexual and so on and so forth, may be an aid to re-vindicate 'the master's tools', as Audre Lorde (1983) once put it, for intellectual and political positioning, but as the womanist completed, 'the master's tools will never dismantle the master's house.'

\section{Intersectionality: at the critical crossroads of a politics of inclusion}

In the spirit of reconstruction, several strategic pathways have been paved to deal with the structures of power that uphold the master's house as we know it today. Looking to intersecting, interacting, interlocking, overlapping, simultaneous forms of oppression enabled a shift intelligible within the hegemonic grammar that permits a (dis)engagement from the reigning binary logic. Moving from either/or to both/and ways of thinking, such critical reorientations increasingly grouped under the umbrella of intersectionality aim to replace 'additive models' of oppression with their delimited (in)dependent variables, and effectuate a paradigm shift based on an Afrocentred epistemic critique that instead of interpolating feminism's universal master/enemy, man, retells history in and beyond the white patriarchy. A retelling of history committed to opening possibilities of resistance, re-existence and resignifications of what Patricia Hill Collins (1986) points to as 'the outsider within.'

From a black feminist epistemology, Collins reworks the 'matrix of domination' so as to account for mutually constructing systems of power. Together with legal scholar and practitioner Kimberlé Crenshaw and numerous other black feminists situated within the US context, she produces a series of conceptual and methodological tools by which to intervene in multi-sited matrixes of domination, from within the fissures of the centre of a global political economy and system of knowledge production. In order to capture what falls between the cracks of a tradition of race thinking that centres black men as subjects and a tradition of gender thinking that centres white women as subjects, the first step to assuming an intersectional lens is to become attentive to the self-definitions and self-evaluations autonomously authored by black women whose structural position re-centres 
what we understand to be racism, sexism and the myriad violences and inequalities that constitute contemporary society.

Collins' notion of the 'outsider within' potentialises perspectives that put in tensionreigning categories of oppression and privilege towards a relational epistemic approach. As the power to (de)legitimate knowledge is authored within the order of a white cisheteronormative masculinity, the task of offering up new angles of discerning the structures of power in society is a strategic endeavour. In Collins' (2000: vii) words,

Oppressed groups are frequently placed in the situation of being listened to only if we frame our ideas in the language that is familiar to and comfortable for a dominant group. This requirement often changes the meaning of our ideas and works to elevate the ideas of dominant groups.

This means, as she continues in the opening pages of On Intellectual Activism (Collins 2013: xiii), that ' $[c]$ hallenging power structures from the inside, working the cracks within the system, however, requires learning to speak multiple languages of power convincingly.'

Self-definition, self-naming and self-evaluations are thus key to unlock the possibilities of the outsider within, as it is by means of this practice that the terms of dispute and its many (dis)qualifications are re-centred. In responding to Eurocentred histories, concepts and methods, an Afrocentred approach retells global history (note: not the history of the other), re-authors concepts (note: not special themes or issues) and proposes methods (note: not alternatives) of grappling with the global racist-sexist-capitalist structures that shape our contemporary world. Afrocentring we access how the codes of masculinity and femininity are conceived in terms of whiteness, and that to centre non-white women and men is to make visible these codes, such as in how Afrocentred definitions of motherhood can reveal such practices as acts of resistance for black women facing genocidal politics in post-colonial societies, and for white women, as a regime of compulsory motherhood set to reproduce the society in force and guarantee patrilineal inheritance.

Yet with the increasing circulation of the concept of intersectionality, its limits and possibilities are being collapsed to explain all, and its intellectual and political proposition effectively distorted. In a recent appeal published in The Washington Post under the title of 'Why intersectionality can't wait', authored by Crenshaw (2015) nearly three decades after putting a name to the concept and lived experience of black women's oppression, the professor of law and executive director of the African American Policy Forum wrote in the wake of the 2015 Charleston church massacre - a historic place of worship as well as an abolitionist and civil rights organisation targeted by white supremacist groups in the USA - to urge a revisioning of social justice that takes seriously the interlocking nature of oppression and what an intersectional perspective has to offer to a project of a truly democratic society.

To this end, Crenshaw reminds us how the concept that put a name to the lived experience of black women emerged, and to what end. She recounts, 
In 1976, Emma DeGraffenreid and several other black women sued General Motors for discrimination, arguing that the company segregated its workforce by race and gender: Blacks did one set of jobs and whites did another. According to the plaintiffs' experiences, women were welcome to apply for some jobs, while only men were suitable for others. This was of course a problem in and of itself, but for black women the consequences were compounded. You see, the black jobs were men's jobs, and the women's jobs were only for whites. Thus, while a black applicant might get hired to work on the floor of the factory if he were male; if she were a black female she would not be considered. Similarly, a woman might be hired as a secretary if she were white, but wouldn't have a chance at that job if she were black. Neither the black jobs nor the women's jobs were appropriate for black women, since they were neither male nor white. Wasn't this clearly discrimination, even if some blacks and some women were hired?

Unfortunately for DeGraffenreid and millions of other black women, the court dismissed their claims. Why? Because the court believed that black women should not be permitted to combine their race and gender claims into one. Because they could not prove that what happened to them was just like what happened to white women or black men, the discrimination that happened to these black women fell through the cracks.

It was in thinking about why such a "big miss" could have happened within the complex structure of anti-discrimination law that the term "intersectionality" was born. As a young law professor, I wanted to define this profound invisibility in relation to the law. Racial and gender discrimination overlapped not only in the workplace but in other arenas of life; equally significant, these burdens were almost completely absent from feminist and anti-racist advocacy. Intersectionality, then, was my attempt to make feminism, anti-racist activism, and anti-discrimination law do what I thought they should — highlight the multiple avenues through which racial and gender oppression were experienced so that the problems would be easier to discuss and understand (Crenshaw 2015).

Within this context, intersectionality was conceived, in Crenshaw's words, as 'an analytic sensibility, a way of thinking about identity and its relationship to power', brought about by black women's experiences of racism and sexism and designed to better comprehend how society works and how relations of power are conjugated at the intersections of racism, sexism, homotransphobia, ableism, classism, among numerous simultaneous systems of oppression and privilege (Crenshaw 2015). Its intellectual and political propo- 
sition, she continues, is aimed at giving advocates 'a way to frame their circumstances and to fight for their visibility and inclusion' (Crenshaw 2015). As 'the banner under which many demands for inclusion have been made,' it has generated much debate around what has come to be called identity politics (Crenshaw 2015). To this, Crenshaw responds,

Of course, as the DeGraffenreid case shows, intersectionality is not just about identities but about the institutions that use identity to exclude and privilege. The better we understand how identities and power work together from one context to another, the less likely our movements for change are to fracture (Crenshaw 2015).

At stake is a reworking of the debate, namely so that white women and non-white men are not the only points of departures for conversations about sexism and racism, respectively. And (not but), its intellectual and political proposition perhaps best serves to intervene within the juridico-normative structures and languages predicated on an abstract subject or notion of individuality mirrored on the image of white men and its narcissistic social, political, economic and cultural norms and standards. That is, it works with/in the hegemonic categories inherited. As the subject of rights can only be accessed on these terms within modern/colonial governing institutions, intersectionality offers numerous possible pathways and strategic responses within the set identitarian terms that position the subject of rights and knowledge evidenced within prevailing feminist and other critical endeavours. Yet given how one subject, in fact, occupies multiple oscillating positions in relation to other subjects and systems of domination (e.g. the position of white women in relation to white men differs qualitatively from the position of white women in relation to non-white men or women), it becomes evident that these contextual dynamics cannot be apprehended by an intersecting of set identitarian categories that does not take into account the historic structuring of the field. After all, as Crenshaw reminds us, the provisional legal concept was put forward to render questions of discrimination legible and intelligible within a juridico-normative frame, to which we need not bind ourselves if our objectives are other within the permanent and multidimensional process of decolonisation in dispute within the global South.

Of course, the many concepts and debates generated by black feminists responding to the complexities of the US contexts cannot be summed up under an identitarian rubric, as thinkers such as Angela Davis (2011) and bell hooks (2007), for instance, take on head first the limits of such propositions in opting for historical analyses of feminism that exceed a conversation about identity/difference, as do Collins' (2000) reworkings of the epistemological foundations of feminism. And here, we are only offering up a few of the names of black feminists whose analyses produced from the USA circulate internationally, and have more visibility, given questions of translation, within the gender debates in the global South, which is the focus of our article. Notwithstanding these diverse articulations of intersectionality, with its exportation and institutionalisation as an academic field of study - and the accompanying weak conception of the geopolitics of the production of knowledge, power and being once exported to the global South - internal critiques and 
disputes that point to problems of the order of the mobilisation of an intersectional method or politics (Nash 2008) often leave silent the why and how such categories have come to be, which can only be accessed in historically localised ways, and the implications of this colonial logic on its many articulations today. That is to say, to complexify and pluralise the meanings of woman, black, and other categories inherited from a colonial modernity can only go so far if the question of what makes someone occupy these positions, here and now, go unanswered.

Beyond the space afforded by a liberal politics of recognition, we inquire here into the limits and possibilities of occupying these demarcated identitarian positions - a question often unanswerable, from within these inherited categories, when posed by transfeminists (Gomes de Jesus 2014), for instance, who propose an effective decolonisation of the body as it has been conceived by the nature/culture divide that regulates categories such as gender, race and sexuality. To access and restore the connections broken by modernity, categories that were never separated to begin with to later be intersected, we need to cultivate imaginaries and sensibilities that perceive that which exceeds, which is informed but not explained by the categories of modern scientific thinking, as a whole. We are talking about a problem far from exclusive to feminist thinking. And it is in this sense that we argue that coloniality and its multiple imbricated hierarchies need to be centred, methodologically, conceptually and politically, within the gender debates of the global South.

Working with hegemonic Eurocentred categories, such as gender, entails a working of the limitations and renunciations of its capacity to grasp what is at stake when talking about that which is placed within its domain. This endeavour requires a rethinking of the relationship between place, political thought and action, so as to understand historical processes in and beyond their hegemonic classifications. Something that no doubt can be undertaken by means of intersectional concepts of the likes developed in the US contexts, but that may not integrate, necessarily, their methodological propositions, something all the more pressing in places subordinated as the global South. The complicities between feminism and the colonial project of modernity, with its conceptions of freedom and equality, of what is a liberated woman, of possible pathways of resistance, beyond the problem of inclusion/exclusion, must be confronted in any and all of its undertakings. Geopolitical positioning implicates in our relations to hegemonic categories of thought, and our capacities to respond to their constant reconfigurations; they are the very conditions of self-inscription and possible articulation of concepts, methods and interventions that reverberate in a given place, for a given people. At heart is a permanent process of dispute, and the question returns to what serves us, rather than a critique and transcendence of particular theoretical projects and the political agendas to which they necessarily respond. The question of what strategies to prioritise, for what disputes, by whom, where, how and to what effects can only be responded to in and from one's own place. Herein lies our capacity to autonomously respond to our own realities, to assume response-ability.

Intersectionality, as we have come to know it, works well within the cracks of messy processes of subjectification forged by the modern/colonial project to make more space for inclusive theorising and practice. By concentrating many of its efforts within the gram- 
mar of identity/difference, vestiges of binary thinking, it reworks the possible space for dispute, composing a series of analytical and political strategies that we do not have the luxury of giving up on. And, the necessity to rework the terms of the debate, the categories and accompanying forms of perceiving and living in the world, must not be foreclosed by the drive to institutionalise intersectional methods within westernised academies worldwide. The necessity to rework the terms of debate makes it that, beyond identifications/ differentiations, we work with structures of relations of power whose narcissistic norms, standards and pacts inform intersubjective and institutional relations in ways that belie the binary as a unitary logic of supremacy rather than as the dyad presented. To speak of women is not to speak of femininity, but to speak of how a logic of masculine supremacy positions itself in relation to that which it subjugates. Far from a problem of women, we can approach it as a problem of men. And in investigating the logic of white supremacy, cisheteronormativity, ableism, etc., it becomes evident that we are not talking about identity and difference, self and other, but of a solipsistic logic from which the world is viewed and theorised and acted upon. We are effectively talking about a false binary, however much it reverberates in the world and opens possibilities for interventions. Yet the question that remains is from what place we choose to perceive the world, and how we respond to where we have been positioned and repositioned in relation to the hierarchisations of our humanities, which we take here as an effect, and not the cause, of the political pacts that sustain the coloniality of knowledge, power and being that organise our worlds today.

That said, intersectionality has generated a vast number of debates previously elided by binary thinking that we must work through in order to appreciate the (im)possibilities of dialogue and political coalitions. It has helped us to look at masculinity in gendered, racialised and classed terms, as Collins (2000) and numerous black feminists and womanists bring to bear on the decontextualising effects of the centrality of sexual difference as a way to think gender in society and the necessity to think in terms of political community. Within the traditions of black feminism in the USA, Sojourner Truth's inaugural speech during the abolitionist struggle, 'Ain't I a woman?' opened pathways to rearticulate intersecting oppression and destabilise the universal subject of woman mirrored on the image of white, middle-upper class women, to a large extent, the wives of a governing elite, as recounted in bell hooks' (hooks 2007) and Angela Davis' (2011) re-narration of hegemonic feminism in the USA. hooks' (2004) recent work extending into the study of masculinity has further elucidated how hegemonic and subordinate masculinities operate to re-force the logic of a white supremacist capitalist society and perpetuate systemic violence against non-white populations. And the burgeoning field of critical masculinity studies (Connell and Messerschmidt 2005) promises to complexify our understanding of what intersectionality takes on, as the unnamed markers of gender (i.e. masculine), race (i.e. white), sexuality (i.e. heterosexual), among other hierarchised categories, are revealed and reworked in their multiple dimensions.

Intersectionality has helped us to see how cisheteronormativity is white, and shapes all gender, class and race relations, such as in the ways Audre Lorde speaks of a less metaphorical master's house, that is, how families are structured as organising units that are fa- 
cilitated or obstructed in literally and metaphorically reproducing the prevailing project of society. Womanist re-articulations of Afrocentred relations of gender, sexuality and class (Hudson-Weems 2001) contribute to conversations that reconceive relationality within and beyond the inherited terms. However not necessarily invested in disputing feminism and other Eurocentred critical praxis, it has put up for debate a number of questions that have opened space for such intellectual and political pursuits. The deconstructions of queer studies (Butler 2004) that have also dialogued with intersectional methods pave the way to loosening our grip on the binary terms of gender thinking and its identitarian logic, so often collapsed into classifications of sexual orientation. And transfeminist contributions (Stryker and Whittle 2006) have long been showing us the way towards an effective decolonisation of the body and a reworking of the terms of gender thinking in its varied political manifestations. Bit by bit these strategic interventions into the field have broadened the scope of our conceptual and political imaginaries.

Intersectionality has also helped us to see how ableism moulds the criteria by which individuality is secured (Sandhal 2003). That is, how gender and sexuality are attributed to bodies deemed fully human, a lesson critical race theory (Solórzano and Yosso 2002) taught us long ago in revealing how non-white bodies have been seen in terms of male/ female, with classifications of the likes of man/woman belonging to the realm of 'civilisation' and humanity at large. Attentive to such (dis)qualifications, we are better situated to perceive how gender, race, class, sexuality, among other categories of oppression and privilege operate.

Intersectionality has ultimately helped to situate concrete subjects (or sociological, as some may say, as opposed to abstract subjects) and non-essentialised identitarian categories through varied standpoints that exceed the binary options charted out by Beauvoir and the white solipsism of hegemonic feminist thinking. Aimed at identifying the corporal terrain where categories of privilege and oppression meet, and what falls between the cracks, it has made possible a mapping of gender, race, sexuality and class as political conjunctures, towards a reworking of the system from and for a diversity of experiences.

And, in its cartographic levelling of variables that enables its subjects and appeals insertion into modern/colonial governing structures, intersectional methods do not, in and of themselves, offer ways to deal with the hierarchisations of our humanity in a (post-) colonial world, in any given context, at any given time or space. Indeed, we never should have asked it to do this for us in the first place. Even from within the margins of the centres of global power (i.e. black feminist productions of knowledge in the USA) - and considering its re-appropriations from within the centres of the margins (i.e. post-colonial elites that emulate colonial and exogenously legitimated logics) - the vast modes of (de)authorisation and (dis)qualification that produce available subject positions within a transversal logic of domination cannot be rendered intelligible in identitarian ways. They can only be accessed historically, in and through places that exceed the (dis)classifications of modern/ colonial systems of governance.

To become attentive to the structuring and structural nature of race, class, sexuality, gender, among other categorisations of humanity, beyond processes of subjectification 
and ensuing inclusions/exclusions, is to see the world anew. It is to cultivate the conditions necessary for a kind of racial and gendered literacy, which attends to the multiple, oscillating and imbricated forms of power that cut across any individualised experience of our inherited world. And with new points of departure, return and reference, it is possible to reset the terms of the debate and move onto a conceptual and political playing field that recognises and works with how gender, race, class and sexuality do not operate on the same plane, as we will seek to flesh out in the next section. In turn, it becomes possible to perceive the master's house otherwise and avoid getting stuck in its trap doors by opening some of its hidden windows.

\section{Imbrication: towards decolonial and diasporic methodologies}

There are many ways to respond to the worlds that we have inherited, their defining terms and disputes. Once the structuring principles are rendered legible, we can take a step back, decentre ourselves and our conceptual and political standpoints, and start thinking strategically about possible pathways within a politics of transformation. No doubt, depending on the context (where, when, what, who, with whom, how, etc.), certain strategies will make more sense than others. The question is how to navigate the regimes of (de)authorisation and (dis)qualification that pit universal against relative or individual against collective logics. To put it more directly, the problem has never been one of identity and difference, but of the political pacts that position norms and standards that privilege some at the costs of others. A logic of domination precedes and structures a logic of identity. And so it is imperative to refine methodological tools capable of discerning how such (dis) orders operate in context, and to what effects. That is to say, what serves us?

Many decolonial approaches seek to rethink this field of (im)possibilities since the modern/colonial constitution of our governing world, situating ourselves in relation to the historic formation of the continent of Abya Yala, and our geopolitical position within the colonial project of modernity and its modes of knowledge production. With this starting point, the basic premise follows that, from the first colonial imposition, there were complex responses from all sides. In this way, it makes us more attentive to the terms through which modern/colonial societies were forged in Abya Yala, cultivating an analytic disposition that looks not only to the violent impositions, or alternatively to the perceptible resistances, but also to the complex negotiations that produced (post-)colonial societies, notably highlighting the effaced contributions of African and indigenous peoples beyond a Eurocentred lens. The decolonial turn now recognised in the westernised social sciences and humanities complements the idea of decolonisation with an approach that is not summed up by chronological narratives or understandings of (de)colonisation and the dynamics of power and resistance. In turn, it promotes a decentring of Europe and a taking up of a sort of frontier thinking by thinkers such as Aníbal Quijano, Immanuel Wallerstein, Sylvia Winters, Ramón Grosfoguel, Edgardo Lander, Augustín Lao-Montes, Walter Mignolo, Enrique Dussel, Fernando Coronil, Santiago Castro-Gómez, Oscar Guardiola, Ana Margarita Cervantes-Rodríguez, María Lugones, Zulma Palermo, Javier 
Sanjinés, Catherine Walsh, Nelson Maldonado-Torres, José David Saldívar, Lewis Gordon, Arturo Escobar, among others who promoted a series of debates and publications between 1996 and 2006 that helped to map out the decolonial project (Castro-Gómez and Grosfoguel 2007) that continues to bring together new voices and representatives. Under this name, decolonial studies - dedicated to tracing the continuities in and beyond the origins and official demise of colonialism, within contemporary structures of political, economic and cultural domination that were founded during this period - has sought visibility as an intellectual and political project over the last two decades, notably centred in the experience of Abya Yala, where post-colonialist and subaltern studies have resonated little or been imported as if with quasi-universal applicability.

Efforts to think gender within decolonial projects have brought to the fore the idea of imbrication as a means to comprehend the structural and structuring nature of categories of oppression and privilege. Afro-Dominican feminist scholar, Ochy Curiel (2016: 80, translation ours), defines the concept and method in the following way:

Understanding the imbrication of oppressions is not about placing categories that make up a sum of experiences, or an intersection of analytical categories (CRENSHAW 1993); it is about understanding how these categories have historically crossed our region from colonialism to contemporary coloniality and as it has been expressed in certain subjects who have not had privileges of race, class, sex and sexuality, as is the case of the black, indigenous and peasant women of the region.

To think gender in ways responsive to the modern/colonial histories of Abya Yala, notably attentive to diasporic movements that shape the ongoing (dis)locations that mark available positions in society, Curiel (2016) brings together, in the essay 'From identities to the imbrication of oppressions,' the pillars of decolonial methodologies that enable us to grapple with the coloniality of power, knowledge and being. Through these approaches to the dynamics of power in societies founded on European colonial slavocratic regimes, which shaped the governing institutions and cultures of servitude in force today, she situates a discussion of gender within the elaboration of the idea of humanity imposed by a colonial modernity, as was initiated in European debates about the non-humanity of indigenous and African peoples colonised, enslaved and trafficked as the basis of developing societies in the centres and peripheries of a global system.

Key to decolonial approaches is the centrality of what has come to be called the 'colonial difference, grounded on a racialised distinction of human/non-human, from which all other hierarchies are articulated through categories such as gender, sexuality and class (Lugones 2010: 936). As a didactic reference in the field, Puerto Rican Ramón Grosfoguel (2016: 11), in 'What is racism?' explains how what we have come to call intersectionality works differently above the line of the human and below the line of the human, highlighting the key influence of Fanon's conception of the zone of being and zone of non-being for thinking through how dynamics of power operate in context. 
From this overarching premise, Curiel points to the concept of the coloniality of being, as proposed by Puerto Rican Nelson Maldonado-Torres (2007), to highlight the negation of humanity in and through the criteria for (dis)qualification of the political, economic, cultural subjectivity imposed, disseminated and internalised as much as by those who qualify as by those who do not (Curiel 2016: 81). Following in Fanon's footsteps, it becomes evident how colonised subjects have been excluded from being judged in terms of humanity and its normative sub-categorisations of the likes of man/woman, but rather, from the perspective of a Eurocentred civilising mission, otherwise categorised as male/ female, such as developed by Argentine María Lugones' (2010: 937) analysis of the coloniality of gender, situated within a modern/colonial binary system whereby colonised subjects and their descendants are sexed but not gendered through the white, masculinised, cisheteronormative codes, standards and pacts.

Together with the coloniality of being and its (dis)qualifications of subjects of humanity, Curiel continues to flesh out the concept of the coloniality of power, also central to a decolonial approach, in terms of how it sheds light on the ways in which such hierarchies have been organised through a standard of power, as put by the Peruvian Aníbal Quijano (2000), sustained by the construction of the idea of race (Curiel 2016: 81). From this mode of operation, Curiel (2016: 81) sums up for us an understanding of the relations of domination and exploitation that pass through disputes over the control of labour, nature, sex and its products for the reproduction of the species; subjectivity, knowledge, authority and its instruments of coercion and numerous other material and intersubjective imperatives to maintaining the structures of power in force.

These dynamics implicate a coloniality of knowledge, which, as decolonial thinkers such as Colombian Santiago Castro-Gómez (2007) put it, is central to the reproduction of a Eurocentred modernity. Curiel (2016: 81, translation ours) identifies this 'type of technical-scientific rationality, or epistemology, that assumes itself as the only valid model of knowledge production' as one of the major obstacles to developing theories and methods that give an account of gender, race, class, sexuality, among other categories of oppression and privilege, across our continent and within post-colonies more broadly.

In this spirit, a commitment to epistemologies of the South demands that we not relegate such ideas, theories and concepts as 'alternatives,' but rather, transform the very mode of knowledge production that positions some ideas as universal and the rest as relative or particular. It is through these terms that Curiel analyses feminist debates within the global South and henceforth proposes the conceptual, political and methodological potential of an imbricated approach, heavily influenced by the intersectional approaches of black feminism, lesbian feminism and Chicana feminism in the context of the USA.

As follows, Curiel explains to us the limits and possibilities of intersectional approaches in the following ways. First, she reflects on how the rise of what has come to be understood as identity politics enabled individual and collective recognition and naming, a reclaimed aesthetics and self-esteem, an exchange of shared experiences, a recovery of an ancestrality lost as a result of racism and sexism since colonial times, and as such the possibility of decolonising cultural and religious practices, as well as bodies and aesthetics, however much questions of essentialism and homogenisation were disputed so as to 
not universalise the subject of black woman as white feminism did of its subject (Curiel 2016: 77). Second, these identitarian and intersectional approaches enabled greater insertion into the public sphere, as tools that evidenced the effects of racism and sexism, notably on black woman, and from such visibility numerous educational policies, social movements and artistic movements took force, even if through the language of discrimination (Curiel 2016: 77). That said, Curiel (2016: 77, translation ours) highlights that within these movements, 'we limited ourselves to see these oppressions as phenomena, that is, to acting on their effects, more as discriminations.' She argues that these discrimination-based perspectives 'did not have the necessary tools to analyse racism and sexism as central epistemes of Western modernity' (Curiel 2016: 77, translation ours). Finally, she argues that the transnationalisation of Afro-Latin and Afro-Caribbean women's networks enabled by an identity politics also resulted in an institutionalisation of these movements and paradigms, resulting in a co-optation by a UN language of human rights based on an individualised subject of rights of a modern/colonial imaginary and its developmentalist renditions within a North-South dynamic.

Reflecting on the dynamics of transnational feminisms in Abya Yala, Afro-Dominican scholar Yuderkys Espinosa-Miñoso advances a decolonial feminist approach that aims to revise the fundamental bases of feminism and extend key concepts of what is known as decolonial theory proposed by diverse thinkers across our continent, such as those aforementioned. In her words,

On the one hand, it claims to be the heir of black, colour and ThirdWorld feminism in the USA, with its contributions to thinking about the imbrication of oppressions (of class, race, gender, sexuality), while proposing to recover the critical legacy of women and Afro-descendant and indigenous feminists from Latin America and the Caribbean who have raised the problem of their invisibility within their movements and within feminism itself, initiating a review of the role and the importance they have had in the realisation and resistance of their communities. Second, the group picks up some contributions from the feminist theory produced in Europe and the USA that serve their purposes. Thus, several of the members of the group take up French materialist feminism with their early questioning of the idea of nature, their understanding of the category of women as 'sex class' and the analysis of heterosexuality as a political regime. They are also nourished by the critical review of essentialism, the subject of feminism and the politics of identity developed by postmodernist feminism. In this same tenor, they recover the legacy of key authors of post-colonial feminism with their critique of epistemic violence, the possibility of a strategic essentialism, the call for a North-South feminist solidarity and the critique of the colonialism of the production of knowledge of the feminist academy based in the north (Curiel 2016: 82, translation ours). 
Working against a long imposed ideological and politico-economic dependence on the global North (as a beacon of what emancipation should look like), as well as the pressures within processes of institutionalisation and technicalisation of feminist movements within the global South, the dialogue established here prioritises an autonomous approach capable of resisting the co-optation of gender thinking and what has come to be understood as identity politics into a human rights agenda ruled by elite interests (Curiel 2016: 78).

Both Espinosa-Miñoso and Curiel begin a re-centring of a decolonial feminist agenda through the recognition of the discursive colonisation of westernised feminisms and its epistemic and politically ethnocentric ideologies of class, race, cisheteronormativity and gender, as well as the collaboration between hegemonic feminism in the global North and the South in the production of subaltern subjects and in the benefit of their own interests. As Espinosa-Miñoso (2009: 45; translation ours) puts it,

Thus, the coloniality of the discursive practices of hegemonic feminisms in the Third World, or in Latin America at least, would not be restricted to a reproduction of the strategies of constitution of the Others of the continent's feminism: Afro-descendant, indigenous, lesbian women, workers, sex workers, peasants, the poor; the effects of the discursive colonisation of western feminisms would imply an intrinsic coloniality to the discourses produced by Latin American feminisms in such a way that it ceases to be only an attribute of the feminisms of the First World and in our lands has at least two other consequences: the definition, in collusion and frank dependence on the hegemonic feminisms of the imperial North, of the guidelines and axes of concern and action of local feminism; and the phagocytisation of the subaltern inhabitants of these lands through their (good) representation by the women of the national elites and the hegemonic feminist groups.

Espinosa-Miñoso identifies, more specifically, how the study of identities has come to predominate gender debates in the academy and feminist movement in the region, specifically in its descriptive undertakings. She continues,

Unfortunately, these studies, focusing on the axes of concern, strategies and conceptualisations legitimised in the central countries have focused mainly on the study of dissident sexualities and gender identity without being able to account for the irreversible intertwining of these orders production of desire, sexuality, and gender with those of race and class, or even the manner in which this constitution of the subject of sexual identity and gender would be produced within a given constitution of Latin American nation-states in contexts of colonial heritage, and discursive colonisation (Espinosa-Miñoso 2009: 46, translation ours). 
At stake is how to articulate, analytically and not merely in descriptive form, the ways in which gender, race, class and sexuality explain the kinds of inequalities and violences that compose post-colonial societies.

As Curiel puts it in her reflections on how the binary divide between nature and culture gave form to the predominant expressions of gender, sexuality and race in modern/ colonial imaginaries, processes of (dis)identification reveal much more than individual or collective attributes, that is,

[T] he categories of gender, race and sexuality do not only lead us to analyse the politics of identity and recognition, as is the tendency of the more postmodern social sciences. They are central categories for analysing relationships and social structures.

The identity politics that has been necessary as a political claim also has its limits. These are unstable, contextualised, and above all political strategies and not ends in themselves. The politics of identity and recognition, so in vogue at this time, is the other face of modernity, today with a hint of postmodernity, which is often either individualised or paradoxically essentialised. Categories like, women, black, indigenous, lesbian, gay, trans, serve us only for political articulation; they cannot be ends in themselves (Curiel 2014: 21, translation ours).

Following these observations into the limits and possibilities of contemporary gender thinking, Curiel articulates a decolonial feminist perspective that prioritises a systematic comprehension of (1) how race and gender are organising principles or 'central epistemes' of a colonial modernity; (2) the relationship between capitalist accumulation and ongoing dispossession of territories inhabited by black and indigenous peoples as well as poor peasants in function of megaprojects of multinational corporations; (3) the interworkings between violence against women and the logic of militarism and trafficking of various sorts; (4) the discourses and policies of national states centred on multiculturalism that sustain a liberal democracy whose paradigm remains modern, white, masculinised, heterosexual and Catholic; and (5) a politics of transformation that goes beyond the positioning of identity politics to give an account of the effects of violences perpetuated by glocal situations and policies (Curiel 2016: 83-84).

It is on these terms that a decolonial and diasporic approach to gender, mobilised through an imbricated methodology, opens up possibilities for dialogue regarding the inequalities and violences that mark our world and position us as subjects of power, knowledge and being. More than an institutional, academic and political space of dispute, this methodological sensibility from the global South turns a key otherwise blocked when we distract ourselves with decontextualised debates, identities and issues or any attempt to import devices elsewhere developed. In turn, this political sensibility opens the strategic pathways for an effective decolonisation of the structures of power, knowledge and being in post-colonial societies of the likes that compose the diverse territories of Abya Yala. 
Lélia Gonzalez, reflecting on the situation of Brazil and the kind of modernisation/ colonisation experimented here, with its politico-economic models and ideological pressures from the centres of global power, offers conceptual tools grounded in a diasporic experience capable of responding to the terms through which our society was forged, and yet not limited to its official boundaries and classifications. In the essay, 'For an Afro-Latin American feminism, she reflects on the quasi-exceptional case of Brazil by pointing to the 'noisy silence surrounding the racial contradictions that are based, in modern times, on one of the most effective myths of ideological domination: the myth of racial democracy' (Gonzalez 1988b: 7, translation ours). Methodologically speaking, when conjugated with the myths of neutrality, universality and individuality of prevailing Eurocentred modes of perceiving and inscribing our realities, in a society like ours that veils its contradictions and inequalities through the language of racial harmony, it becomes imperative to develop conceptual tools that render legible the terms of domination, whose racism is articulated through an ideology of whitening instead of more explicit or ostensible modes of segregation (Gonzalez 1988a: 72-73).

To this end, Gonzalez develops the 'politico-cultural category' of amefricanidade (Amefricanity) that recognises and works with the indigenous, African and European contributions (however unequally positioned) through which the continent was forged, working against the effacement of the first two towards an analytic sensibility that perceives the inner workings of 'a historical process of intense cultural dynamics (adaptation, resistance, reinterpretation and creation of new forms) that is Afrocentred' (Gonzalez 1988a: 76, translation ours). More than a geographic or linguistic category, its methodological contribution is to think a 'specific unity', with all of its apparent contradictions (Gonzalez 1988a: 77). It is from this point of departure that we call forward a rethinking of our relationship to place, political thought and action. With this imbricated sensibility, what we understand of gender, sexuality, class and race relations changes, for neither the hegemonic discourse nor the perceptible resistance in and of itself explains how they are lived, experimented and negotiated here and now. From this sensibility, Gonzalez (1988b: 4 , translation ours) leaves us with the following challenge:

For all this, Latin American feminism loses much of its strength by abstracting from a fact of reality that is of great importance: the multiracial and pluricultural character of the societies of that region. To deal, for example, with the sexual division of labour without articulating it with its correspondent on a racial dimension, is to fall back on a kind of abstract universal rationalism, typical of a masculinised and white discourse. To speak of the oppression of Latin American women is to speak of a generality that obscures, I emphasise, that removes from the scene the harsh reality lived by millions of women who pay a very high price for not being white. 


\section{Final considerations}

A decolonial and diasporic perspective that takes seriously the inextricable connection between coloniality and modernity enables us to reflect on the racialised, classed and gendered hierarchies that structure contemporary society; the normalisation of sexuality and (dis)abled bodies; and the appropriation of nature that has imposed itself on Amefrican territories since the fifteenth century at the inauguration of the European colonial slavocratic project. That is, its conceptual and political lenses enable a comprehensive account of the standards of normality and political pacts that have come to define the 'insiders' and the 'outsiders.' When we locate ourselves and our histories, and accordingly reorient the attendant theories, methods and concepts, what we grasp of relations of gender, race, class, sexuality, among other categories of oppression and privilege, is not only what the official narratives or counter-narratives tell us. It is imperative that we re-centre our points of departure, return and reference so that they respond to the context at hand.

In the diverse contexts of the global South, identifying intersecting points of identity, difference and accompanying discriminations neither explains nor opens possibilities for an effective decolonisation of the structures of power, knowledge and being. For our systems of domination are not thoroughly hegemonic, and nor are our hegemonic systems anchored in a material basis of domination of compatible reach, given our exogenous formation as colonies and foreign trade companies whose institutional and intersubjective relations were set to privilege the protection of private property so as to serve a metropolis beyond one's borders. As Fanon taught us, societies founded on a colonial slavocratic project are profoundly marked by a zone of being and a zone of non-being, where the humanity of some is guaranteed by the questioning, hierarchising and negation of the humanity of others. These governing logics often exceed what reason is able to capture, and as such it is necessary to undertake a political reading of the complex, ambivalent and oscillating relations of power that together sustain the dominant project of society.

In the face of these multiple imbricated systems of domination, exogenously formed, a decolonial and diasporic sensibility is oriented towards the creation of new civilisational standards, so to speak, and not only the protection of the subalternised within the current system, for the problem with marginalisation is with those who marginalise, with the structures that position some at the centre and others at the margins. The problem is in how the very standards are conceived so as to maintain the frontier between the zone of being and the zone of non-being that constitute contemporary society, its political pacts and its notion of democracy. It is high time to assume the incommensurabilities that separate much more than the polarisations seem to present. It is in the face of the incommensurabilities that a real dispute for democracy can offer truly democratic ways of (re)building political pacts between us that take as non-negotiable the affirmation of our equal humanity.

To speak of gender is to speak of the categorisations of humanity. There are simply no conceptual or political means by which to isolate a gender variable, in intellectually rigorous or politically responsible ways, independent of the object of study. As follows, binary and intersecting approaches, as much as they may draw our attention to particular 
dynamics of power and their juridico-normative ramifications, are limited in their capacity to discern the structural and structuring dynamics of gendering processes in context, beyond a descriptive or identitarian account of relations of power. Their institutionalisation and reconfigurations of the gender debates in the global South make evident these pending risks, however much the central problem is quite simply that they were mobilised to respond to realities otherwise situated. To work towards an effectively global dialogue, beyond the exchange of critiques and the overcoming of discredited theoretical models anchored in a singular measure of intelligibility, it is imperative to confront the geopolitics of the production of knowledge that necessarily mediate our relations to hegemonic categories such as gender inherited from the European modern/colonial project. It is vital to cultivate the conditions necessary to respond to the formative relationships between place, political thought and action. It is in this sense that we propose a discussion here that centres coloniality in rethinking the limits of modernity. In sum, a gendered lens must offer us more than a cataloguing of identity and difference, of problems of inclusion, exclusion and discrimination; at stake are the very standards, norms, ideals and pacts that structure the (im)possibilities of our inherited present. At stake is re-existence.

\section{References}

Anzaldúa, Glória. 2000. 'Falando em línguas: uma carta para as mulheres escritoras do terceiro mundo.' Translated by Édna de Marco. Estudos Feministas 8 (1): 229-236.

Bairros, Luiza. 1995. 'Nossos Feminismos Revisitados'. Estudos Feministas 3 (2): 458-463.

Beauvoir, Simone de. 2011. The Second Sex. Translated by Constance Borde and Sheila Malovany-Chevallier. New York: Vintage Books.

Bento, Berenice. 2006. A Reinvenção do Corpo: Sexualidade e Gênero na Experiência Transsexual. Rio de Janeiro: Editora Garamond.

Bernardino-Costa, Joaze and Ramón Grosfoguel. 2016. 'Decolonialidade e perspectiva negra'. Sociedade e Estado 31 (1): 15-24.

Butler, Judith. 2004. Undoing Gender. New York: Routledge.

Castro-Gómez, Santiago and Ramón Grosfoguel. 2007. 'Prólogo. Giro decolonial, teoría crítica y pensamiento heterárquico.' In Santiago Castro-Gómez and Ramón Grosfoguel (eds), El giro decolonial: reflexiones para una diversidade epistémica más allá del capitalismo global. Bogotá: Siglo del Hombre Editores, pp. 9-23.

Collins, Patricia Hill. 1986. 'Learning from the outsider within: The sociological significance of black feminist thought.' Social Problems 33 (6):14-32.

2000. Black Feminist Thought: Knowledge, Consciousness, and the Politics of Empowerment. London: Routledge. 2013. On Intellectual Activism. Philadelphia: Temple University Press.

Connell, R W and James W Messerschmidt. 2005. 'Hegemonic masculinity: Rethinking the concept.' Gender and Society 19 (6): 829-859. 
Crenshaw, Kimberlé. 1993. 'Demarginalizing the intersection of race and sex: A black feminist critique of antidiscrimination doctrine, feminist theory, and antiracist politics.' In Kelley D Weisberg (ed), Feminist Legal Theory: Foundations. Philadelphia: Temple University Press, pp. 383-397.

2015. 'Why intersectionality can't wait.' The Washington Post, 24 September.

Curiel, Ochy. 2014. 'Género, raza, sexualidad: debates contemporâneos.' Colombia: Universidad del Rosario. At http://www.urosario.edu.co/urosario_files/1f/1f1d1951-0f7e-43ff-819f-dd05e5fed03c. pdf [Accessed on 12 January 2018].

. 2016. 'De las identidades a la imbricación de las opresiones: desde la experiência.' In Ana

Flauzina and Thula Pires (eds), Encrespando: Anais do I Seminário Internacional Refletindo a Década Internacional dos Afrodescendentes (ONU 2015-2024). Brasília: Brado Negro, pp. 75-85.

Davis, Angela. 2011. Women, Race, \& Class. New York: Knopf Doubleday.

Espinosa-Miñoso, Yuderkys. 2009. 'Etnocentrismo y colonialidad en los feminismos latinoamericanos: complicidades y consolidación de las hegemonías feministas en el espacio transnacional.' Revista Venezolana de Estudios de La Mujer 14 (33): 37-54.

Fanon, Frantz. 2008. Black Skin, White Masks. Translated by Charles Lam Markmann. London: Pluto Press.

Gomes de Jesus, Jaqueline (ed). 2014. Transfeminismo: Teorias e Práticas. Rio de Janeiro: Metanoia Editora.

Gonzalez, Lélia. 1988a. 'A categoria político-cultural de amefricanidade.' Tempo Brasileiro 92/93: 69-82.

1988b. 'Por um feminismo afrolatinoamericano’. Revista Isis Internacional 9: 133-141.

Grosfoguel, Ramon. 2016. 'What is racism?' Journal of World-system Research 22 (1): 9-15.

hooks, bell. 2004. The Will to Change: Men, Masculinity, and Love. New York: Simon and Schuster.

2007. Ain't I a Woman: Black Women and Feminism. Boston: The South End Press.

Hudson-Weems, Clenora. 2001. 'Africana womanism: The flip side of a coin.' The Western Journal of Black Studies 25 (3): 137-145.

Lorde, Audre. 1983. 'The master's tools will never dismantle the master's house.' In Cherrie Moraga and Gloria Anzaldúa (eds), This Bridge Called My Back: Writings by Radical Women of Color. New York: Kitchen Table Press, pp. 25-28.

Lugones, María. 2010. 'Toward a decolonial feminism.' Hypatia 25 (4): 742-759.

Meneses, Maria Paula and Boaventura de Sousa Santos (eds). 2010. Epistemologias do Sul. São Paulo: Editora Cortez.

Nash, Jennifer. 2008. 'Re-thinking intersectionality’. Feminist Review 89 (1): 1-15.

Okin, Susan Moller. 1989. Gender, Justice, and The Family. New York: Basic Books.

Oyèwùmí, Oyèronké. 2000. 'Laços familiares/ligações conceituais: notas africanas sobre epistemologias feministas.' Translated by Aline Matos da Rocha. Signs 25 (4): 1093-1098.

2004. 'Conceituando o gênero: os fundamentos eurocêntricos dos conceitos feministas e o desafio das epistemologias africanas.' Translated by Aline Matos da Rocha. In Signe Arnfred, Bibi Bakare-Yusuf and Edward Waswa Kisiang'ani (eds), African Gender Scholarship: Concepts, Methodologies and Paradigms. Dakar: CODESRIA, pp. 1-8.

Pateman, Carole. 1988. The Sexual Contract. Redwood: Stanford University Press. 
Quijano, Aníbal. 2000. 'Colonialidad del poder, eurocentrismo y América Latina.' In Edgardo Lander (ed), La colonialidad del saber: eurocentrismo y ciencias sociales. Perspectivas latino-americanas. Buenos Aires: CLACSO.

Sandhal, Carrie. 2003. 'Queering the crip or cripping the queer? Intersections of queer and crip identities in solo autobiographical performance.' GLQ: A Journal of Lesbian and Gay Studies 9 (1-2): 25-56.

Solórzano, Daniel G and Tara J Yosso. 2002.'Critical race methodology: Counter-storytelling as an analytical framework for education research.' Qualitative Inquiry 8 (1): 23-44.

Spivak, Gayatri Chakravorty. 1997. 'Feminismo e desconstrução, de novo: negociando com o masculinismo inconfesso.' In Teresa Brennan (ed), Para Além do Falo: Uma Crítica a Lacan do Ponto de Vista da Mulher. Translated by Alice Xavier. Rio de Janeiro: Editora Rosa dos Tempos, pp. 277-297. Stryker, Susan and Stephen Whittle (eds). 2006. The Transgender Studies Reader. New York: Routledge.

Vigoya, Mara Viveros. 2018. As Cores da Masculinidade: Experiências Interseccionais e Práticas de Poder na Nossa América. Translated by Allyson de Andradae Perez. Rio de Janeiro: Papéis Selvagens.

\section{About the authors}

Thula Pires is a professor and undergraduate co-ordinator of the Law Department at Pontifícia Universidade Católica do Rio de Janeiro, Brazil. She has a doctorate in Constitutional Law and State Theory from the same university, and is an associate researcher at the Center for Constitutional Studies. She is currently the coordinator of the Interdisciplinary Center for African Descendent Research and Heritage (NIREMA). Her areas of concentration include: racism; critical race theory; black women; human rights; and the theory of recognition.

Andréa Gill is a professor and research practitioner at the Institute of International Relations at Pontifícia Universidade Católica do Rio de Janeiro, Brazil. She has a doctorate in Political Science and Cultural, Social, and Political Thought from the University of Victoria, and is an associate researcher at the Interdisciplinary Center for African Descendent Research and Heritage (NIREMA). Her areas of concentration include: post-colonial and decolonial studies; race, class, sexuality, and gender relations; urban politics and globalisation; political economy and development; and Latin American social and political thought. 


\section{Da Abordagem Binária à Interseccional à Imbricada: Gênero em uma Perspectiva Decolonial e Diaspórica}

Resumo: Este artigo propõe uma releitura do problema de gênero ou, como tem sido colocado, na maior parte das vezes, 'o problema da mulher', a partir dos sistemas de poder moderno/colonial e suas normas, padrões, ideais e pactos políticos. Nesse sentido, busca-se abrir um diálogo com concepções de gênero que respondam às dinâmicas que forjaram as sociedades modernas/coloniais em Abya Yala, inspirando-se nas perspectivas decolonial e afrodiaspórica. Para este fim, o artigo mapeia alguns dos canais disponíveis do debate de gênero no que veio a ser conhecido como o Sul global e que destacam as maneiras pelas quais as relações entre categorias de opressão e privilégio (como raça, classe, sexualidade e gênero) são refletidas e posicionadas de modo a lidar com a colonialidade do saber, do poder e do ser. O objetivo principal é investigar as condições político-epistêmicas que estruturam o pensamento de gênero de forma binária e interseccional e, por sua vez, abrir espaço para abordagens imbricadas e forjadas a partir de histórias que tomam como ponto de partida referências teóricas de lugares situados como "outros" dentro de uma economia política global de saber/poder/ser. Mais do que uma crítica dos pontos de vista teóricos do Norte global, em si e de si mesmos, aqui são analisados os termos através dos quais gênero e feminismos foram colocados em debate para responder às nossas realidades. Propõe-se recentrar as referências que pautam as discussões de gênero no contexto de Abya Yala para que não se perca a dimensão do que está em jogo quando se reivindica gênero como categoria política, normativa e analítica: as (im)possibilidades de viver a humanidade plena nos próprios termos.

Palavras-chave: interseccionalidade; imbricação; descolonialidade; gênero; raça; amefricanidade; Abya Yala.

Received on 30 January 2018, and approved for publication on 9 April 2019.

https://creativecommons.org/licenses/by-nc/4.0/ 